\title{
Diversity and Conservation status of Mammals in Wang Kelian State Park, Perlis, Malaysia
}

\author{
Vijaya Kumaran Jayaraj ${ }^{1,2 *}$, Siti Hajjar Muhamad Daud ${ }^{1}$, Mohd-Isham Azhar ${ }^{3}$, Shahrul Anuar Mohd \\ Sah $^{2}$, Seri Intan Mokhtar ${ }^{4}$ and Mohd Tajuddin Abdullah ${ }^{2}$ \\ 1 Universiti Malaysia Kelantan, Faculty of Earth Science, 17600 Jeli, Kelantan, Malaysia \\ 2 Universiti Sains Malaysia, School of Biological Sciences, 11800, Penang, Malaysia. \\ 3 Universiti Malaysia Sarawak, Department of Zoology, Faculty of Resource Science and Technology, 94300 Kota Samarahan, Sarawak, Malaysia \\ 4 Universiti Malaysia Kelantan, Faculty of Agro Based Industry, 17600 Jeli, Kelantan, Malaysia. \\ * Corresponding author. E-mail: jayarajvijayakumaran@gmail.com
}

\begin{abstract}
A series of surveys in Wang Kelian State Park, Perlis were carried out since 2009 to 2011 to document the diversity of mammals. Two sampling stations; 1) the Wang Burma cave trail and 2) the Orchard leading to Tasik Meranti were sampled for small mammals using mist-nets, harp traps, cage traps and were accounted through direct observation. The highlight of this study includes new geographic records for Rhinolophus chiewkweeae and Rousettus leschenaultii for the state of Perlis. Additionally, there were also 30 new distributional records of mammals in this protected area, increasing the total known mammals of Wang Kelian State Park to 86 species. Although having poorly known mammals such as $R$. chiewkweeae and Macaca arctoides in this park, the diversity of mammals in Wang Kelian State Park is still underestimated as the species cumulative curve over time has yet to reach a stationary phase. In conclusion more surveys need to be done especially the northern part of the park near the Malaysia-Thailand border and Tasik Meranti in order to look at possible occurrences of threatened mammals highlighted in this study.
\end{abstract}

\section{INTRODUCTION}

Malaysia, one of the 17 megadiverse countries has a very unique assemblage of mammals. There are 344 species of mammals known to occur in Malaysia which is approximately $6.2 \%$ of the total known mammals in the world (IUCN 2012). The abundance of these mammals varies from common to rare and diversity and composition of mammals differs in different habitats across the country. As Malaysia has a smaller land mass but high diversity of mammals, the threat of extinction is very much imminent if no careful management is in place. Twenty one species mammals in Malaysia are currently Endangered or Critically Endangered, and this reflects the threat that many other species of mammals may face in the near future (IUCN 2012). Protected areas serves as reservoir habitats for these mammals, thus a good understanding on the diversity and abundance of mammals in protected areas is crucial for conservation and management purposes.

Wang Kelian State Park situated in northwest Perlis within the Nakawan Range from $06^{\circ} 43.5^{\prime} \mathrm{N}$ to $100^{\circ} 10.5^{\prime}$ E. It is the first protected area to be established in the northern part of Peninsular Malaysia and it forms a transfrontier protected area with the Thaleban National Park in Satun, Thailand (Muhamad and Abang 2011). Beside this, Wang Kelian State Park also has its ecotourism attractions such as the Wang Burma Cave I and II and a marked trail that leads to Gunung Perlis. Perlis being the most northern state in Peninsular Malaysia, has several unique mammals such as Macaca arctoides, Bandicota indica and $B$. bengalensis which are not found in the southern part of this country (Latiff et al. 2002). Although M. arctoides is common in other regions of mainland South and Southeast Asia, Wang Kelian State Park is the only protected area in Peninsular Malaysia where this species can be found.
Both Bandicoot Rats (B. indica and B. bengalensis) are introduced species originated from that can be found in the northern region of Peninsular Malaysia. However up to date there are no records of these rodents in Wang Kelian State Park.

Previous surveys back in 1992, 1993 and 2002 indicate that Wang Kelian State Park has a total of 59 species of mammals (Sharma 1992; DWNP 1993; Shukor et al. 2002a, b). Given the strategic positioning of this state park and the fact that this area is the only site in Peninsular Malaysia where semi-deciduous forest occurs, it is crucial that ongoing surveys to document biodiversity of the protected area should be carried out. Thus a series of surveys were done as a continuous effort by Universiti Sains Malaysia together with Universiti Kebangsaan Malaysia (since 2002) and Universiti Malaysia Kelantan (recently) to document the total mammalian diversity in this site. The current survey results are an update to the information on mammalian species richness and their conservation status in this protected area.

\section{Materials ANd Methods}

Permission to enter at Wang Kelian State Park, Perlis was approved by Forestry Department of Perlis and permission to conduct research on wildlife was approved by the Department of Wildlife and National Parks, Malaysia. The assessment of the diversity of mammals at Wang Kelian State Park, Perlis (Figure 1) was conducted from 2009-2011 for four sampling periods: 1) 27-29 March 2009, 2) 2-4 April 2010, 3) 11-13 March 2011 and 4) 27-3 November 2011. Trapping were carried out at 2 sampling stations; 1) along the trail leading to Wang Burma Cave I and II, and 2) an orchard near Meranti Lake. Mist nets and four-bank harp traps were placed in presumed flyways 
to capture bats whereas cage traps baited with banana were placed in the forest floor to capture non-volant small mammals. Mist nets and harp traps were checked from 19:00h to 23:00h and the nets were closed for the night. The mist nets were reopened the next morning and both nets and harp traps checked from 05:00h to 08:00h.

We made opportunistic observation and identification of both diurnal and nocturnal mammals when possible and identified following Francis (2008). All standard measurements including weight, sex and maturity state of captured mammals were recorded following Francis (2008). Euthanasia of vouchers was done using a high dose of chloroform. These vouchers were then tagged and preserved in 70\% ethanol and were deposited in Zoological Repository at Faculty of Earth Science, Universiti Malaysia Kelantan (UMK). The results were presented as a list of species recorded and compared with previous surveys conducted in year 1992. We also compared the current conservation status of these mammals in IUCN Red List of Threatened Species (2012, http://www.iucnredlist.org/) and DWNP (2010) Red list of Mammals for Peninsular Malaysia. This listing follows the current taxonomic designation by Wilson and Reeder (2005). Only two red list criteria (criteria $A$ and $B$ ) were compared as none of the species are listed in criteria $C$ - red list criteria for population size estimates and population trends. Criteria $A$ refers to change in population size and criteria $B$ is for change in the geographic range of the extent of occurrence (EOO) or area of occupancy (AOO) of the species.

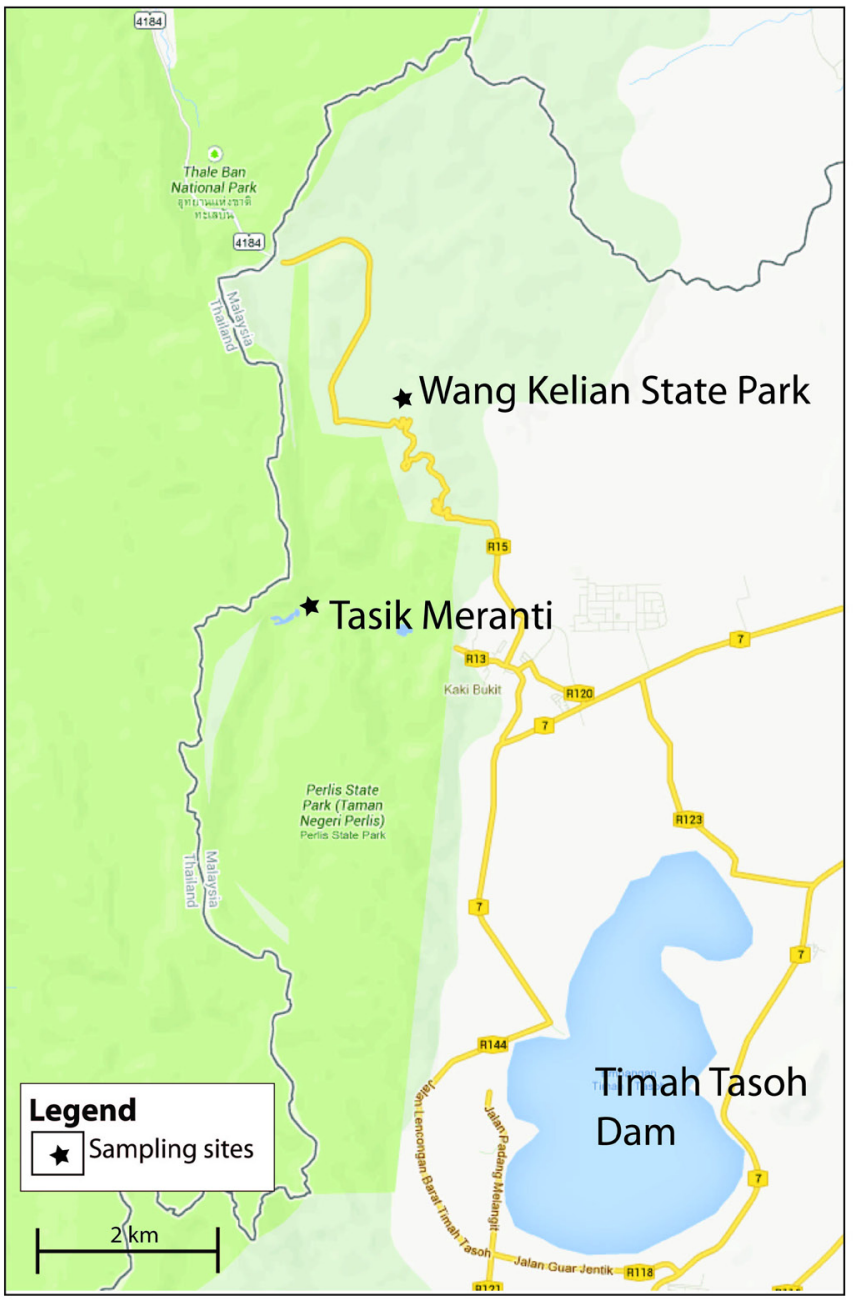

FIGURE 1. Map of study site indicating sampling stations.

\section{RESULTS AND Discussion}

The total trapping effort for this study was 937 trap nights/days (35 mist-net nights; 32 harp trap nights; 870 cage trap days; see Table 1). The major findings of this study include new distributional record for Rhinolophus chiewkweeae and the poorly known Rousettus leschenaultii in Perlis and 30 new distributional records for mammals in Wang Kelian State Park. This brings the total known mammals found in Wang Kelian State Park to 86 species. A total of 769 individuals (348 in 2009, 188 in 2010, 144 in March and 89 in November 2011 respectively) were captured and these were represented by 19 species of non-volant mammals and 34 species of bats (Table 1 ).

The most abundant species of bats in this survey was Hipposideros larvatus as it had the highest total capture in all sampling sessions since 2009 ( $n=288$; see Table 1). This species had the highest total capture in all sampling sessions since 2009 with a total capture rate of 4 bats per mist-net/trap night (based on 69 mist-net and harp trap nights). Other abundant species of mammals in this state park were $H$. armiger $(\mathrm{n}=132)$. For non-volant small mammals, Tupaia glis $(\mathrm{n}=21)$ was the most abundant followed by Maxomys rajah and $M$. surifer. Fifteen species were caught as singletons in our survey and are listed as follow: Rousettus leschenaultii, Balionycteris maculata, Macroglossus sobrinus, Megaderma spasma, Nycteris tragata, Rhinolophus trifoliatus, R. chiewkweeae, Hipposideros dyacorum, H. cervinus, H. galeritus, Murina suilla, Kerivoula papillosa, Callosciurus notatus, Rattus rattus and Mus musculus (Table 1; see Appendix 1 for museum collections made and Appendix 2 for some of the pictures of mammals recorded in this study).

Our opportunistic observation of mammals throughout the September 2011 survey recorded mammals from the Order Primates and Carnivora. These were Macaca fascicularis, M. arctoides, M. nemestrina, Trachypithecus obscurus, Paguma larvata and Paradoxus hermaphroditus (P. hermaphroditus listed here does not include those caught in cage traps). This survey added 32 new mammalian species record for Wang Kelian State Park whch was not previously recorded in field survey reported by Shukor et al. (2002a, 2002b). In contrary, a total of 32 species of mammals that were previously recorded in this park that were not recorded in present study (Shukor et al., 2002a, 2002b; Table 1). Currently, Wang Kelian State Park holds 37 \% (86/232 species) of terrestrial mammals known in Peninsular Malaysia [list of mammals in Table 1 compared to Francis (2008) and Kingston et al. (2003; 2006)]. Species cumulative curve over time showed a sharp increase in species richness (Figure 2). However, this curve is yet to reach an asymptotic condition, indicating possibilities of underestimation of mammalian species richness in this protected area.

Listed together in Table 1 is the current conservation status (DWNP 2010; current IUCN Red List of Threatened Species 2012) of known mammals in Wang Kelian State Park. Other common mammals previously caught were less in the last survey period because the placing of nets and traps were altered to increase the possibilities of documenting different species in the area through increasing diversity of microhabitats sampled. Table 2 is the current conservation status (DWNP 2010; IUCN 2012) 
of known mammals in Wang Kelian State Park. The current IUCN Red List of Threatened Species (2012) placed all 86 known mammals from this protected area into the following categories of conservation status: 4 species as Endangered; 7 species as Vulnerable; 10 species as Near Threatened; 65 species as Least Concern; while 1 species Rhinolophus chiewkweeae were not assessed as this is a newly described species. Note however for $C$. brachyotis and $H$. bicolor complex there are still distinct morphotypes that have yet to be described. In $C$. brachyotis, at least one known form yet to be described ( $C$. cf. brachyotis Forest; see Francis, 2008; Abdullah and Jayaraj 2006; Jayaraj et al. 2012) was collected in this study ( $\mathrm{n}=3$ from the total 10 individuals; identified using methods described in Jayaraj et al. 2012). For $H$. bicolor, two recognized forms distinguishable by echolocation calls $(131 \mathrm{kHz}$ and 142 kHz; see Khan et al. 2008) may be present in Wang Kelian State Park. For Criteria A in DWNP (2010), only 12 species conservation status were assessed, with 4 species were listed as Endangered, 5 species as Vulnerable and 3 species as Near Threatened. For Criteria B, a total of 81 species of mammals were evaluated with 5 species were listed as Endangered, 4 species as Vulnerable while the rest $(72$ species) were categorized as Least Concern. Hipposideros bicolor and 3 species of rodents (Callosciurus caniceps, Sundasciurus lowii and Niviventer fulvescens) were not assessed in DWNP (2010).

Rhinolophus chiewkweeae (Yoshiyuki and Lim 2005), a newly described Rhinolophus is only known from limited localities within Peninsular Malaysia. This includes Langkawi Island, mainland Kedah, Melaka and Johor. Our survey increased the distribution of this species to the northern tip of Peninsular Malaysia (Figure 3; Yoshiyuki and Lim 2005). According to the IUCN Redlist of Threatened Species (IUCN 2012), Rousettus leschenaultii is not found in Peninsular Malaysia but data from this study and Moseley et al. (2012) have extended the current distributional records of this species to Peninsular Malaysia from Wang Kelian State Park to Batu Caves, Selangor (Figure 3).

Together with the new record of $R$. chiewkweeae and $R$. leschenaultii in Perlis, we managed to record 32 new records of mammals in this state park (20092011) indicating that the mammalian diversity of Wang Kelian State Park was poorly described in the past. The beginning of the exponential curve in 2009 (Figure 2) was due to the fact that there were no surveys since 2002 and the usage of other sampling methods which caused a sudden increase of new records. Our observation indicates that higher sampling effort for small mammals in a wide variety of microhabitats would increase the knowledge on mammalian diversity in Wang Kelian State Park (similarly suggested in Khan et al. 2008).

Comparison of cage trapping capture rate in this study was $9 \%$ (number of individuals/trap effort), higher than $6 \%$ capture rate in the primary forest (Lim B.L. pers comm.) but we found that a higher capture rate of small mammals does not translate into higher species diversity; rather it increases the capture rate of common non-volant small mammals found in that area. Our data showed that between 27 October to 3 November 2011, T. glis (18 out of total 38 individuals of non-volant small mammals caught) dominated our capture in Wang Kelian State Park (Table 1). In previous mammal diversity surveys at Gunung Jerai (Kedah), high trapping effort and capture rate ( $>7000$ cage trapping days) recorded only 18 species of non-volant small mammals (Shahrul-Anuar et al. 2006, Mark Rayan and Shahrul-Anuar 2006). Kingston et al. (2003) used a wide variety of methods and targeted various habitats to document bat diversity in Krau Wildlife Reserve and their survey produced 18 new bat distribution records. We speculate that the documentation of small mammals can be maximized by actually selecting multiple microhabitats for trap placement rather than only increasing trapping effort per se. This trapping strategy is expected to increase the diversity of small mammals recorded and at the same time decrease the occurrence of recapture especially the common species.

Large mammals observed during this survey were mostly primates and civets. Four species of primates including $M$. arctoides, $M$. nemestrina, $M$. fasicularis and T. obscurus were recorded throughout the 7 day/night sampling session in November 2011. Macaca arctoides and M. nemestrina are listed as Vulnerable, T. obscurus is listed as Near Threatened and M. fasicularis is listed as Least Concern in the IUCN Redlist of Threatened Species (2012). A group of $M$. arctoides was sighted on a hill roadside near Wang Kelian State Park. In Malaysia, this species is only known from Perlis (see Figure 3), thus the conservation priority is higher (Endangered) in The Redlist of Peninsular

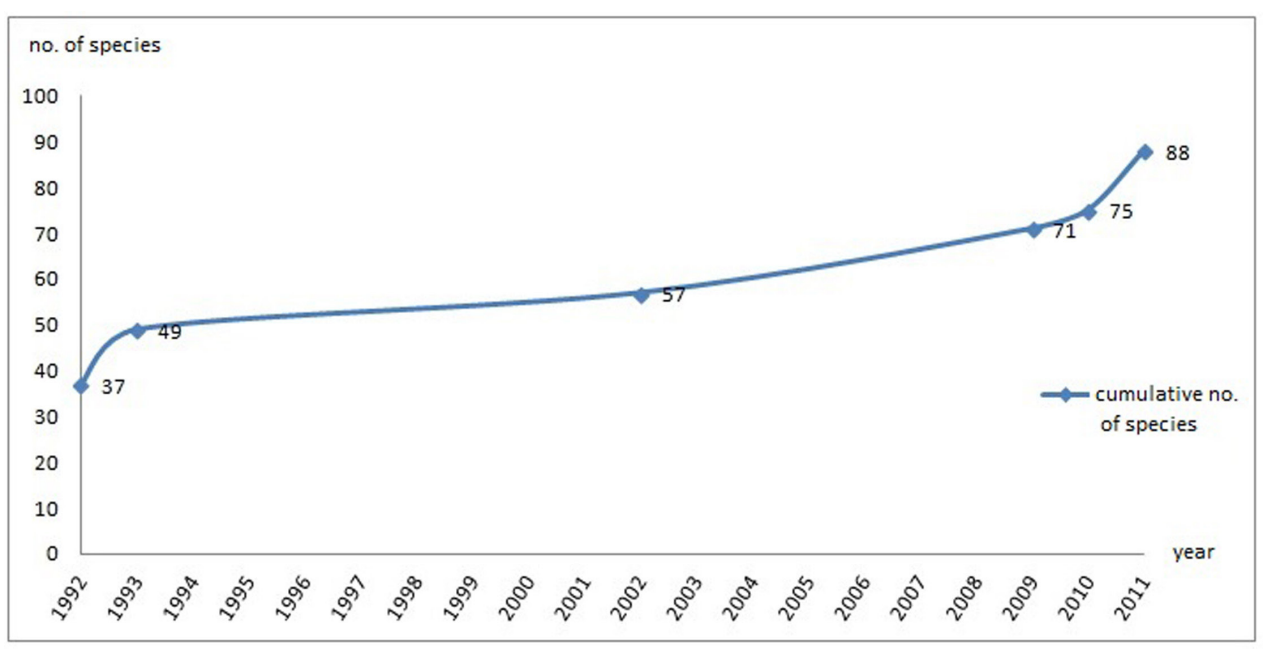

FIGURE 2. Mammal species cumulative curve over time (year) based on studies conducted since 1992 to 2011 in Wang Kelian State Park, Perlis. 


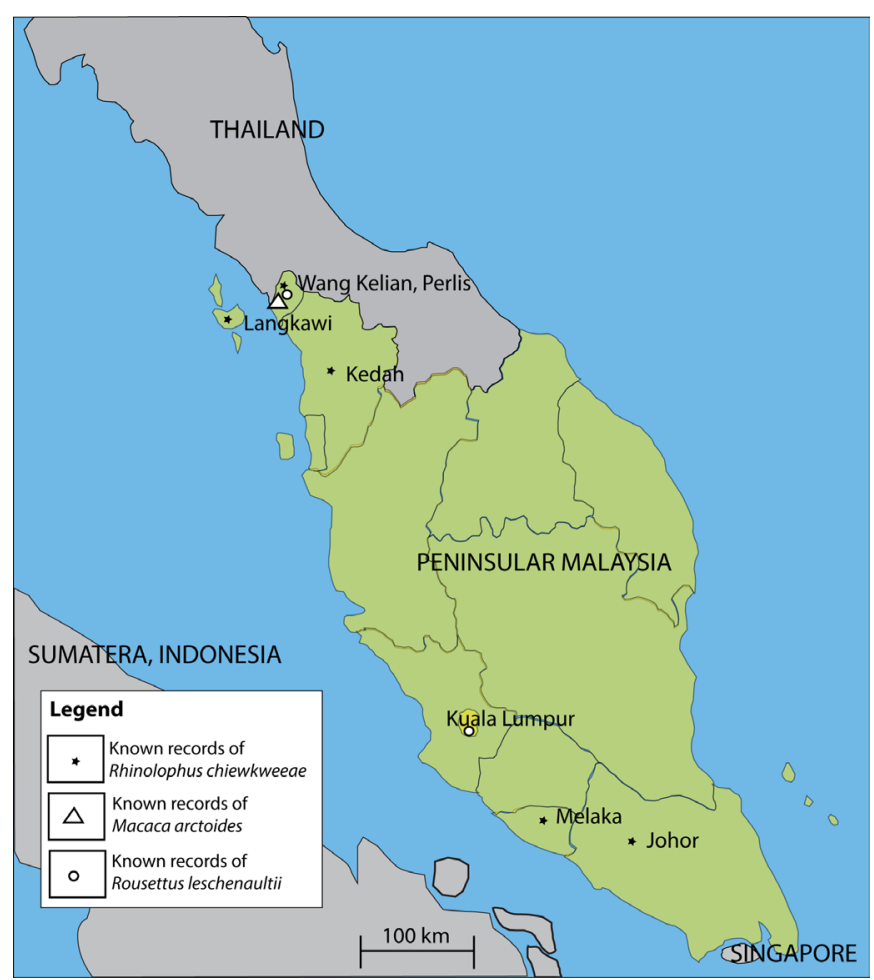

FIGURE 3. The putative current distribution of Rhinolophus chiewkweeae, Rousettus leschenaultii and Macaca arctoides in Peninsular Malaysia

Malaysian Mammals (DWNP 2010), but in contrary at a global scale this species is less prioritized (Vulnerable). This comparison highlights some of the discrepancies. The contrasting data between DWNP (2010) and IUCN Redlist of Threatened Species (2012) also indicates that the global assessment does not necessarily cater to the local conservation needs especially in globally widespread species but has a restricted distribution eg. $R$. leschenaultii.
A thorough assessment at the regional level following IUCN's criteria would be the best approach to determine conservation priorities in Malaysia.

Civets were occasionally observed during spotlighting in the night and we managed to record two species of civets (Paguma larvata and Paradoxus hermaphroditus). The conservation status of both of these species were listed as Least Concern in both conservation status assessments (DWNP 2010; Duckworth et al. 2008a, 2008b). In the rural areas of Pengkalan Chepa (Kelantan) electric poles and cables have been found to be effective corridors for civets to travel between patches of vegetation, avoiding traffic and tar roads at night. Thus these mammals can survive in highly modified landscapes, as long as there is a supply of food source.

At present the mammalian species richness of Wang Kelian State Park is still underestimated and may require additional surveys with using different field sampling methods before an overall estimate of the mammalian diversity can be understood. Our study also highlighted the importance of this protected area for $M$. arctoides that are more common in the northern mainland Southeast Asia region but can only be found in this state park within Peninsular Malaysia. Additionally, species records of $R$. chiewkweeae and Rousettus leschenaultii from Wang Kelian that are poorly known in Malaysia further strengthen the importance of this protected area. These records and together with a total of 87 species of mammals now known from this state park indicates that this protected area is a vital area for conservation of mammals in Peninsular Malaysia. Further surveys should be conducted at the northern part of the protected area near the MalaysiaThailand and also Tasik Meranti as these areas may reveal more mammalian species record that yet to be recorded from Wang Kelian State Park.

TABLE 1. Chronology of mammal surveys in Wang Kelian State Park, Perlis outlining mammals known to this state park and the sampling effort of this study. The current conservation status (IUCN 2012 and DWNP 2010) of mammals in Wang Kelian State Park, Perlis are also shown.

\begin{tabular}{|c|c|c|c|c|c|c|c|c|c|c|}
\hline & \multicolumn{3}{|c|}{$\begin{array}{c}\text { Previous } \\
\text { studies }\end{array}$} & \multicolumn{4}{|c|}{ Current study } & \multirow{2}{*}{$\begin{array}{l}\text { IUCN } \\
\text { status }\end{array}$} & \multicolumn{2}{|c|}{ DWNP status } \\
\hline & 1 & 2 & 3 & $\begin{array}{c}27-29 \\
\text { Mar 2009 } \\
\end{array}$ & $\begin{array}{c}2-4 \\
\text { Apr } 2010 \\
\end{array}$ & $\begin{array}{c}11-13 \\
\text { Mar 2011 } \\
\end{array}$ & $\begin{array}{c}27 \text { Oct-3 Nov } \\
2011 \\
\end{array}$ & & A & B \\
\hline Manis javanica & $\sqrt{ }$ & & & & & & & $E n A 2 d+3 d+4 d$ & VU A4cd & \\
\hline \multicolumn{11}{|l|}{ ERINACEOMORPHA } \\
\hline Echinosorex gymnurus & $\sqrt{ }$ & $\sqrt{ }$ & & 1 & 1 & 1 & & LC & VU A4e & LC \\
\hline Crocidura fuliginosa & $\sqrt{ }$ & & & & & & & LC & & LC \\
\hline \multicolumn{11}{|l|}{ SORICOPMORPHA } \\
\hline Tupaia glis & $\sqrt{ }$ & $\sqrt{ }$ & $\sqrt{ }$ & 3 & & & 18 & $\mathrm{LC}$ & & LC \\
\hline Tupaia minor & $\sqrt{ }$ & & & & & & & $\mathrm{LC}$ & VU A4c & $\begin{array}{c}\text { VU } \\
\text { B2ab(iii) }\end{array}$ \\
\hline \multicolumn{11}{|l|}{ DERMOPTERA } \\
\hline Galeopterus variegatus & $\sqrt{ }$ & & $\sqrt{ }$ & & & & & LC & & LC \\
\hline \multicolumn{11}{|l|}{ CHIROPTERA } \\
\hline Rousettus leschenaultii ${ }^{A A}$ & & & & & & & 1 & LC & & $\begin{array}{c}\text { EN } \\
\text { B2ab(ii,iii) }\end{array}$ \\
\hline Cynopterus brachyotis & & $\sqrt{ }$ & $\sqrt{ }$ & 1 & & & 10 & $\mathrm{LC}$ & & LC \\
\hline Cynopterus sphinx & $\sqrt{ }$ & & & & & & 5 & $\mathrm{LC}$ & & $\mathrm{LC}$ \\
\hline Cynopterus horsfieldii ${ }^{A}$ & & & & & & & 6 & $\mathrm{LC}$ & & LC \\
\hline Megaerops ecaudatus ${ }^{A}$ & & & & & & & 6 & $\mathrm{LC}$ & & $\mathrm{LC}$ \\
\hline Balionycteris maculata ${ }^{A}$ & & & & & & & 1 & LC & & LC \\
\hline Eonycteris spelaea & & & $\sqrt{ }$ & & & & & $\mathrm{LC}$ & & LC \\
\hline Macroglossus sobrinus ${ }^{A}$ & & & & & & & 1 & $\mathrm{LC}$ & & $\mathrm{LC}$ \\
\hline
\end{tabular}


TABle 1. Continued.

\begin{tabular}{|c|c|c|c|c|c|c|c|c|c|c|}
\hline & \multicolumn{3}{|c|}{$\begin{array}{l}\text { Previous } \\
\text { studies }\end{array}$} & \multicolumn{4}{|c|}{ Current study } & \multirow{2}{*}{$\begin{array}{l}\text { IUCN } \\
\text { status }\end{array}$} & \multicolumn{2}{|c|}{ DWNP status } \\
\hline & 1 & 2 & 3 & $\begin{array}{c}27-29 \\
\text { Mar } 2009 \\
\end{array}$ & $\begin{array}{c}2-4 \\
\text { Apr } 2010 \\
\end{array}$ & $\begin{array}{c}11-13 \\
\text { Mar } 2011 \\
\end{array}$ & $\begin{array}{c}27 \text { Oct-3 Nov } \\
2011 \\
\end{array}$ & & A & B \\
\hline Macroglossus minimus & & & $\sqrt{ }$ & & & & & LC & & LC \\
\hline Nycteris tragata ${ }^{A}$ & & & & 1 & & & & NT & & $\mathrm{LC}$ \\
\hline Megaderma spasma & & & $\sqrt{ }$ & & & 1 & & LC & & $\mathrm{LC}$ \\
\hline Rhinolophus trifoliatus $^{A}$ & & & & 1 & & & & $\mathrm{LC}$ & & $\mathrm{LC}$ \\
\hline Rhinolophus macrotis ${ }^{A}$ & & & & & & 2 & 1 & $\mathrm{LC}$ & & $\mathrm{LC}$ \\
\hline Rhinolophus coelophyllus & & $\sqrt{ }$ & & 1 & 4 & 3 & & $\mathrm{LC}$ & & $\mathrm{LC}$ \\
\hline Rhinolophus lepidus & & $\sqrt{ }$ & & 2 & 3 & 2 & 1 & $\mathrm{LC}$ & & LC \\
\hline Rhinolophus affinis & $\sqrt{ }$ & $\sqrt{ }$ & & 2 & 31 & 36 & 5 & LC & & $\mathrm{LC}$ \\
\hline Rhinolophus stheno ${ }^{A}$ & & & & & 2 & & & LC & & LC \\
\hline Rhinolophus malayanus $^{A}$ & & & & 1 & 1 & & & $\mathrm{LC}$ & & $\mathrm{LC}$ \\
\hline Rhinolophus robinsoni ${ }^{A}$ & & & & 17 & 1 & 2 & & NT & & $\mathrm{LC}$ \\
\hline Rhinolophus chiewkweea $e^{A A}$ & & & & & & & 1 & Not assessed & & $\begin{array}{c}\text { VU } \\
\text { B2ab(ii,iii) }\end{array}$ \\
\hline Hipposideros bicolor ${ }^{A}$ & & & & 4 & 30 & 17 & & $\mathrm{LC}$ & $\begin{array}{c}\text { Not } \\
\text { assessed }\end{array}$ & $\begin{array}{c}\text { Not } \\
\text { assessed }\end{array}$ \\
\hline Hipposideros dyacorum ${ }^{A}$ & & & & & & & 1 & $\mathrm{LC}$ & EN A4c & $\begin{array}{c}\text { EN } \\
\text { B2ab(ii,iii) }\end{array}$ \\
\hline Hipposideros doriae ${ }^{A}$ & & & & 36 & 3 & & & NT & & $\begin{array}{c}\mathrm{VU} \\
\mathrm{B} 2 \mathrm{ab}(\mathrm{ii}, \mathrm{iii})\end{array}$ \\
\hline Hipposideros cervinus ${ }^{A}$ & & & & 1 & & & & LC & & LC \\
\hline Hipposideros galeritus ${ }^{A}$ & & & & 1 & & & & LC & & $\mathrm{LC}$ \\
\hline Hipposideros larvatus & & $\sqrt{ }$ & & 127 & 95 & 60 & 6 & LC & & $\mathrm{LC}$ \\
\hline Hipposideros diadema & $\sqrt{ }$ & $\sqrt{ }$ & & & & & 2 & LC & & $\mathrm{LC}$ \\
\hline Hipposideros armiger $^{4}$ & & & & 119 & 6 & 6 & 1 & LC & & $\mathrm{LC}$ \\
\hline Myotis montivagus ${ }^{A}$ & & & & 6 & & & & $\mathrm{LC}$ & & $\mathrm{LC}$ \\
\hline Myotis siligorensis & & & & & & & 2 & LC & & $\begin{array}{c}\mathrm{VU} \\
\mathrm{B} 2 \mathrm{ab}(\mathrm{ii}, \mathrm{iii})\end{array}$ \\
\hline Pipistrellus stenopterus & & & $\sqrt{ }$ & & & & & LC & & LC \\
\hline Tylonycteris robustula & $\sqrt{ }$ & & & & & & & $\mathrm{LC}$ & & $\mathrm{LC}$ \\
\hline $\begin{array}{l}\text { Murina peninsularis }{ }^{A} \text { (see } \\
\text { Francis and Eger 2012). }\end{array}$ & & & & 1 & 1 & & & $\mathrm{LC}$ & & $\mathrm{LC}$ \\
\hline Murina aenea & & $\sqrt{ }$ & & & & & & $\mathrm{VU} A 2 c+3 c$ & & LC \\
\hline Murina suilla ${ }^{A}$ & & & & & 1 & & & LC & & $\mathrm{LC}$ \\
\hline Kerivoula papillosa ${ }^{A}$ & & & & & 1 & & & $\mathrm{LC}$ & & $\mathrm{LC}$ \\
\hline Kerivoula hardwickii ${ }^{A}$ & & & & 1 & 1 & & 1 & $\mathrm{LC}$ & & $\mathrm{LC}$ \\
\hline Kerivoula pellucida ${ }^{A}$ & & & & 13 & 1 & 1 & & NT & & $\mathrm{LC}$ \\
\hline Kerivoula intermedia ${ }^{A}$ & & & & 3 & & 1 & & NT & $\begin{array}{c}\text { VU } \\
\text { B2ab(ii,iii) }\end{array}$ & \\
\hline \multicolumn{11}{|l|}{ PRIMATES } \\
\hline Ncyticebus coucang & & & $\sqrt{ }$ & & & & & VU A2cd & & $\mathrm{LC}$ \\
\hline Presbytis femoralis & $\sqrt{ }$ & $\sqrt{ }$ & & & & & & NT & & $\mathrm{LC}$ \\
\hline Trachypithecus obscurus* & $\sqrt{ }$ & $\sqrt{ }$ & & & & & Spotted & NT & & $\mathrm{LC}$ \\
\hline Macaca nemestrina ${ }^{* A}$ & & & & & & & Spotted & VU A2cd & & LC \\
\hline Macaca arctoides* & $\sqrt{ }$ & & & & & & Spotted & VU A3cd+4cd & EN A4c & $\begin{array}{c}\text { EN } \\
\text { B2ab(ii,iii) }\end{array}$ \\
\hline Macaca fascicularis* & $\sqrt{ }$ & $\sqrt{ }$ & $\sqrt{ }$ & & & & Spotted & $\mathrm{LC}$ & & $\mathrm{LC}$ \\
\hline Hylobates lar & $\sqrt{ }$ & $\sqrt{ }$ & & & & & & En A2cd & & LC \\
\hline \multicolumn{11}{|l|}{ CARNIVORA } \\
\hline Helarctos malayanus & $\sqrt{ }$ & $\sqrt{ }$ & & & & & & $\begin{array}{c}\mathrm{VU} \\
\mathrm{A} 2 \mathrm{~cd}+3 \mathrm{~cd}+4 \mathrm{~cd}\end{array}$ & VU A2d & $\mathrm{LC}$ \\
\hline Paradoxurus hermaphroditus* & $\sqrt{ }$ & $\sqrt{ }$ & $\sqrt{ }$ & & & 1 & 4 & LC & & LC \\
\hline Paguma larvata* & $\sqrt{ }$ & & $\sqrt{ }$ & & & & Spotted & LC & & LC \\
\hline Herpestes urva & $\sqrt{ }$ & & & & & & & LC & EN A4c & $\begin{array}{c}\text { EN } \\
\text { B2ab(ii,ii) }\end{array}$ \\
\hline Panthera pardus & $\sqrt{ }$ & & & & & & & NT & EN A4d & LC \\
\hline Prionailurus bengalensis & & $\sqrt{ }$ & & & & & & $\mathrm{LC}$ & & LC \\
\hline \multicolumn{11}{|l|}{ PERISSODACTYLA } \\
\hline Tapirus indicus & & $\sqrt{ }$ & & & & & & En A2cd & NT & LC \\
\hline \multicolumn{11}{|l|}{ ARTIODACTYLA } \\
\hline Sus scrofa & $\sqrt{ }$ & $\sqrt{ }$ & & & & & & $\mathrm{LC}$ & & LC \\
\hline Tragulus kanchil & $\sqrt{ }$ & $\sqrt{ }$ & & & & & & LC & & $\mathrm{LC}$ \\
\hline
\end{tabular}


TABLE 1. CONTINUED.

\begin{tabular}{|c|c|c|c|c|c|c|c|c|c|c|}
\hline & \multicolumn{3}{|c|}{$\begin{array}{c}\text { Previous } \\
\text { studies }\end{array}$} & \multicolumn{4}{|c|}{ Current study } & \multirow{2}{*}{$\begin{array}{l}\text { IUCN } \\
\text { status }\end{array}$} & \multicolumn{2}{|c|}{ DWNP status } \\
\hline & 1 & 2 & 3 & $\begin{array}{c}27-29 \\
\text { Mar 2009 }\end{array}$ & $\begin{array}{c}2-4 \\
\text { Apr } 2010 \\
\end{array}$ & $\begin{array}{c}11-13 \\
\text { Mar 2011 } \\
\end{array}$ & $\begin{array}{c}27 \text { Oct-3 Nov } \\
2011 \\
\end{array}$ & & A & B \\
\hline Muntiacus muntjak & $\sqrt{ }$ & $\sqrt{ }$ & & & & & & LC & NT & LC \\
\hline Capricornis sumatraensis & $\sqrt{ }$ & $\sqrt{ }$ & & & & & & VU A2cd & NT & $\mathrm{LC}$ \\
\hline \multicolumn{11}{|l|}{ RODENTIA } \\
\hline Ratufa bicolor & $\sqrt{ }$ & & & & Spotted & & & NT & & LC \\
\hline Ratufa affinis & & $\sqrt{ }$ & & & & & & NT & & LC \\
\hline Callosciurus prevostii & $\sqrt{ }$ & $\sqrt{ }$ & $\sqrt{ }$ & & & & & $\mathrm{LC}$ & & LC \\
\hline Callosciurus notatus & $\sqrt{ }$ & & & & & & 1 & $\mathrm{LC}$ & & LC \\
\hline Callosciurus caniceps & $\sqrt{ }$ & & & & & & & $\mathrm{LC}$ & $\begin{array}{c}\text { Not } \\
\text { assessed }\end{array}$ & $\begin{array}{c}\text { Not } \\
\text { assessed }\end{array}$ \\
\hline Sundasciurus lowii & $\sqrt{ }$ & & & & & & & $\mathrm{LC}$ & $\begin{array}{c}\text { Not } \\
\text { assessed }\end{array}$ & $\begin{array}{c}\text { Not } \\
\text { assessed }\end{array}$ \\
\hline Sundasciurus tenuis ${ }^{A}$ & & & & & 1 & 1 & & $\mathrm{LC}$ & & LC \\
\hline Lariscus insignis & $\sqrt{ }$ & $\sqrt{ }$ & & & 1 & 1 & 3 & LC & & LC \\
\hline Petaurista petaurista & & & $\sqrt{ }$ & & & & & $\mathrm{LC}$ & & LC \\
\hline Pteromyscus pulverulentus & & $\sqrt{ }$ & & & & & & $\begin{array}{c}\mathrm{En} \\
\mathrm{A} 2 \mathrm{c}+\mathrm{A} 3 \mathrm{c}+\mathrm{A} 4 \mathrm{c}\end{array}$ & & LC \\
\hline Rattus rattus & & & & & & & 1 & LC & & LC \\
\hline Rattus tiomanicus & $\sqrt{ }$ & & & & & & & LC & & LC \\
\hline Berylmys bowersi & $\sqrt{ }$ & & & & & & & $\mathrm{LC}$ & & $\begin{array}{c}\text { EN } \\
\text { B2ab(ii,iii) }\end{array}$ \\
\hline Sundamys muelleri & & $\sqrt{ }$ & & 1 & 1 & 2 & & $\mathrm{LC}$ & & $\mathrm{LC}$ \\
\hline Niviventer fulvescens ${ }^{A}$ & & & & & & & 2 & $\mathrm{LC}$ & $\begin{array}{c}\text { Not } \\
\text { assessed }\end{array}$ & $\begin{array}{c}\text { Not } \\
\text { assessed }\end{array}$ \\
\hline Leopoldamys sabanus & $\sqrt{ }$ & $\sqrt{ }$ & & 2 & 1 & 3 & 3 & $\mathrm{LC}$ & & $\mathrm{LC}$ \\
\hline Maxomys surifer & & & $\sqrt{ }$ & & 1 & 1 & & LC & & LC \\
\hline Maxomys rajah & $\sqrt{ }$ & $\sqrt{ }$ & $\sqrt{ }$ & 3 & 1 & 3 & 3 & VU A2c & & LC \\
\hline Mus musculus ${ }^{A}$ & & & & & & & 1 & $\mathrm{LC}$ & & LC \\
\hline Chiropodomys gliroides & $\sqrt{ }$ & & & & & & & $\mathrm{LC}$ & & $\mathrm{LC}$ \\
\hline Hystrix brachyura & $\sqrt{ }$ & $\sqrt{ }$ & & & & & & $\mathrm{LC}$ & & $\mathrm{LC}$ \\
\hline Mist nets effort & - & - & - & 0 & 0 & 0 & 35 & - & - & - \\
\hline Harp traps effort & - & - & - & 4 & 8 & 6 & 14 & - & - & - \\
\hline Cage traps effort & - & - & - & 150 & 150 & 150 & 420 & - & - & - \\
\hline Total effort & - & - & - & 154 & 158 & 156 & 469 & - & - & - \\
\hline Total individuals captured & - & - & - & 348 & 188 & 144 & 89 & - & - & - \\
\hline Total species recorded & 38 & 29 & 16 & 24 & 23 & 19 & 36 & - & - & - \\
\hline Total Orders recorded & 10 & 8 & 6 & 4 & 3 & 4 & 5 & - & - & - \\
\hline
\end{tabular}

Previous studies: 1 = Sharma (1992); 2 = PERHILITAN (1993); 3 = Shukor et al. (2002a, b)

$\sqrt{ }=$ recorded; number refers to trapping data; spotted are species spotted via visual observation. ${ }^{\mathrm{AA}}$ new record for Perlis. ${ }^{\mathrm{A}}$ New record for Wang Kelian State Park.

For IUCN Red List (2012), the guidelines for conservation status criteria are outlined in http://www.iucnredlist.org/documents/RedListGuidelines.pdf. For DWNP (2010) guidelines for conservation status criteria are outlined in Part IV The Categories in 'Red List of Mammals For Peninsular Malaysia. Department of Wildlife and National Parks Peninsular Malaysia, available at http://www.wildlife.gov.my/images/stories/penerbitan/lain_lain/ Redlist\%20Final.pdf;

criteria $A$ - red list criteria for change in population size;

criteria $B$ - red list criteria for change in the geographic range of the extent of occurrence (EOO) or area of occupancy (AO0) of the species. None of the species listed are listed in criteria $\mathrm{C}$ - red list criteria for population size estimates and population trends.

ACKNowledgments: We would like to thank the Forestry Department, Perlis and the Department of Wildlife and National Parks, Malaysia for their approval to enter and conduct the research on wildlife at Wang Kelian State Park, Perlis. We extend our gratitude to Universiti Malaysia Kelantan (UMK) for logistic supports, Universiti Sains Malaysia (USM) and Universiti Malaysia Sarawak (UNIMAS) for their various administrative supports. We would also like to thank Mr Md Azam Md Rami and Miss Amirah Mohd Fikri who helped us in the sampling activity. We are also thankful to the anonymous reviewer for giving constructive comments that significantly improve the quality of the manuscript. This study was partially funded by several grants: two Ministry of Higher
Education Fundamental Research Grants (MOHE FRGS): R/FRGS/ A03.00/00481A/002/2011/000043 awarded to JVK, ZH, MTA, YE, FAAK and JRRJ and FRGS/01(23)/766/2010(47) awarded to MTA, one Ministry of Higher Education Research Acculturation Collaborative Effort (RACE) grant R/RACE/A07.00/00525A/002/2012/000085 awarded to SIM, JVK, SAM, ASO and MTA, R/MTSF/A03.00/00481A/003/2012/000071 Universiti Malaysia Kelantan Short Term Grant (UMK SGJP): R/SGJP/ A03.00/00481A/001/2010/000037) awarded to JVK, WYC and ARA, and Malaysian Toray Science Foundation Science and Technology Grant 2012 (MTSF 2012): R/MTSF/A03.00/00481A/003/2012/000071 awarded to JVK, SIM and SAMS. 


\section{LITERATURE CITED}

Abdullah, M.T. and V.K. Jayaraj. 2006. Preliminary investigation on the relationship of the nominate $C$. brachyotis with the small-sized and large-sized $C$. brachyotis using clustering analysis. Sarawak Museum Journal 62: 223-236.

Duckworth, J.W., P. Widmann, C. Custodio, , J.C. Gonzalez, , A. Jennings, and G. Veron. 2008a. Paradoxurus hermaphroditus. In IUCN 2012. IUCN Red List of Threatened Species. Version 2012.1. Electronic database accessible at www.iucnredlist.org. Captured on 13 July 2012.

Duckworth, J.W., C. Wozencraft, and B. Kanchanasaka. 2008b. Paguma larvata. In IUCN 2012. IUCN Red List of Threatened Species. Version 2012.1. Electronic database accessible at www.iucnredlist.org. Captured on 13 July 2012.

DWNP, 2010. Red list Of Mammals For Peninsular Malaysia. Kuala Lumpur: Department of Wildlife and National Parks Peninsular Malaysia. 150 p.

Francis, C.M. 2008. A field guide to the mammals of South-East Asia. NewHolland: United Kingdom. 392 p.

Francis, C.M. and J.L. Eger. 2012. A review of Tube-Nosed Bats (Murina) from Laos with a description of two new species. Acta Chiropterologica $14(1): 15-38$

IUCN, 2012. IUCN Red List of Threatened Species. Version 2011.2. Electronic database accessible at www.iucnredlist.org. Captured on 24 April 2012.

Jayaraj V.K., C.J. Laman and M.T. Abdullah. 2012. A predictive model to differentiate $C$. brachyotis from $C$. cf. brachyotis Forest (Chiroptera: Pteropodidae) from Malaysia using Multivariate Analysis. Zoological Studies 51(2): 259-271.

Khan, F.A.A., V.J. Swier, P.A. Larsen, S. Solari, K. Besar, M. Wahap, S. Ellagupillay, M. Marklarin, M.T. Abdullah and R.J. Baker. 2008. Using Genetics and Morphology to Examine Species Diversity of Old World Bats: report of a recent collection from Malaysia. Occasional Papers at Museum of Texas Tech University 281: 1-27.

Kingston, T., C.M. Francis, A. Zubaid and T.H. Kunz 2003. Species richness in an insectivorous bat assemblage from Malaysia. Journal of Tropical Ecology 19: 67-79.

Kingston, T., B.L. Lim and Z. Akbar. 2006. Bats of Krau Wildlife Reserve. Kuala Lumpur: Universiti Kebangsaan Malaysia Publishers. 148 p.

Latiff , A., O. Kasim, A.R. Yusoff and I.H. Faridah. 2002. Biodiversity and Management of Perlis State Park Physical, Biological and Social Environment of Wang Mu. Perlis: Jabatan Perhutanan Negeri Perlis. $407 \mathrm{p}$.

Mark Rayan, D. and M.S. Shahrul Anuar. 2006. Relative abundance of non-volant small mammal population at two different altitudes at Gunung Jerai; p 433-442 In M.I. Shaharuddin, W.A. Wan Yusoff, Md. Som, Jalil., M. Yusoff and A. Latiff (ed.). Hutan Simpan Gunung Jerai, Kedah: Pengurusan, persekitaran fizikal dan kepelbagaian biologi. Kuala Lumpur: Forestry Department of Peninsular Malaysia.

Muhamad I.I. and F. Abang. 2011. Short Note New Distributional Record of Hypochrosis cryptopyrrhata Walker, 1862 (Geometridae: Ennominae) from Peninsular Malaysia. Tropical Natural History 11(1): 71-73.

PERHILITAN 1993. Cadangan penubuhan pengurusan dan pengurusan Taman Negeri Wang Kelian Perlis Indera Kayangan. Kuala Lumpur: PERHILITAN.

Shahrul-Anuar M.S., E. Nurul 'Ain, M. Nor Zalipah, D. Mark Rayan, D. Shukor, M. Ganesan and S. Kalimuthu. 2006. Diversity of small mammals (non-volant) at Gunung Jerai; p. 433-442 In M.I. Shaharuddin, W.A. Wan Yusoff, Md. Som, Jalil., M. Yusoff and A. Latiff (ed). Hutan Simpan Gunung Jerai, Kedah: Pengurusan, persekitaran fizikal dan kepelbagaian biologi. Kuala Lumpur: Forestry Department of Peninsular Malaysia.

Sharma, D. 1992. Survey of Mata Ayer Forest Reserve and the proposed Bukit Wang Mu Forest Reserve, Perlis. Kuala Lumpur: WWF Malaysia. $121 \mathrm{p}$.

Shukor, M.N., M.S. Shahrul-Anuar, M.H. Baharuddin, Y. Ahmad, M. Ganesan and M.Z. Kamili. 2002a. Tinjauan mamalia kecil di Tasik Meranti, Taman Negeri Perlis; p. 181-192 In A. Latiff, K. Osman, Y.A. Rahaman and I. Faridah-Hanum (ed.). Biodiversity and management of Perlis State Park. Physical, biological and social environments of Wang $\mathrm{Mu}$. Perlis: Perlis State Park/Department of Forestry.

Shukor, M.N., M.S. Shahrul-Anuar, R. Wong, Y. Ahmad, M. Ganesan and J.P. Besar. 2002b. Ecology and diversity of small mammals and bats in Wang Burma Forest Reserve, Perlis State Park; p. 210-231 In A. Latiff, K. Osman, Y.A. Rahaman and I. Faridah-Hanum (ed.). Biodiversity and management of Perlis State Park. Physical, biological and social environments of Wang $M u$. Perlis: Perlis State Park/Department of Forestry.

Wilson, D.E. and D.M. Reeder. 2005. Mammal Species of the World: A Taxonomic and Geographic References. Washington DC: Smithsonian Institution Press.

Yoshiyuki, M. and B.L. Lim. 2005. A new horseshoe bat, Rhinolophus chiewkweeae (Chiroptera, Rhinolophidae), from Malaysia. Bulletin of the National Science Museum, Tokyo, Series A 31: 29-36.

RECEIVED: December 2012

ACCEPTED: November 2013

Published ONLINE: November 2013

EDITORIAL RESPONSIBILITY: Marcelo Passamani

APPENDIX 1. List of museum specimens and the voucher accession numbers collected as new records in this survey.

\begin{tabular}{ll} 
SPECIES & MUSEUM ACCESSION NO. \\
\hline Rousettus leschenaultii & PSP 033 \\
Cynopterus cf. brachyotis forest & PSP001, PSP003, PSP005 \\
Cynopterus horsfieldii & PSP0022, PSP030, PSP047 \\
Megaerops ecaudatus & PSP0026, PSP028, PSP029 \\
Balionycteris maculata & PSP004 \\
Macroglossus sobrinus & PSP053 \\
Rhinolophus macrotis & PSP050 \\
Rhinolophus chiewkweeae & PSP051 \\
Hipposideros armiger & PSP070 \\
Kerivoula hardwickii & PSP075 \\
Niviventer fulvescens & PSP060, PSP061 \\
Mus musculus & PSP068 \\
\hline
\end{tabular}




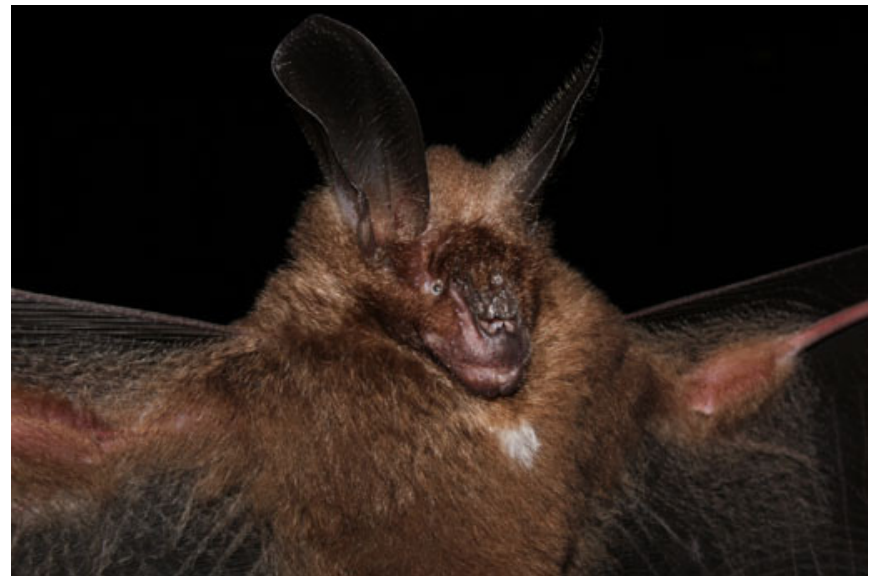

Nycteris tragata

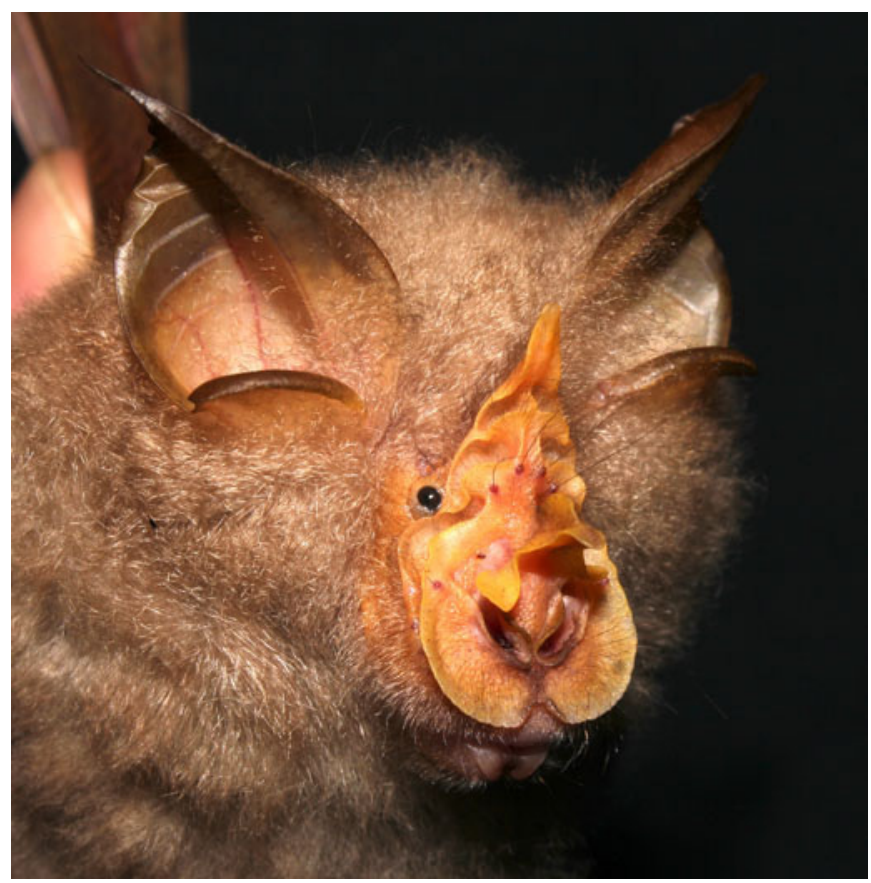

Rhinolophus trifoliatus

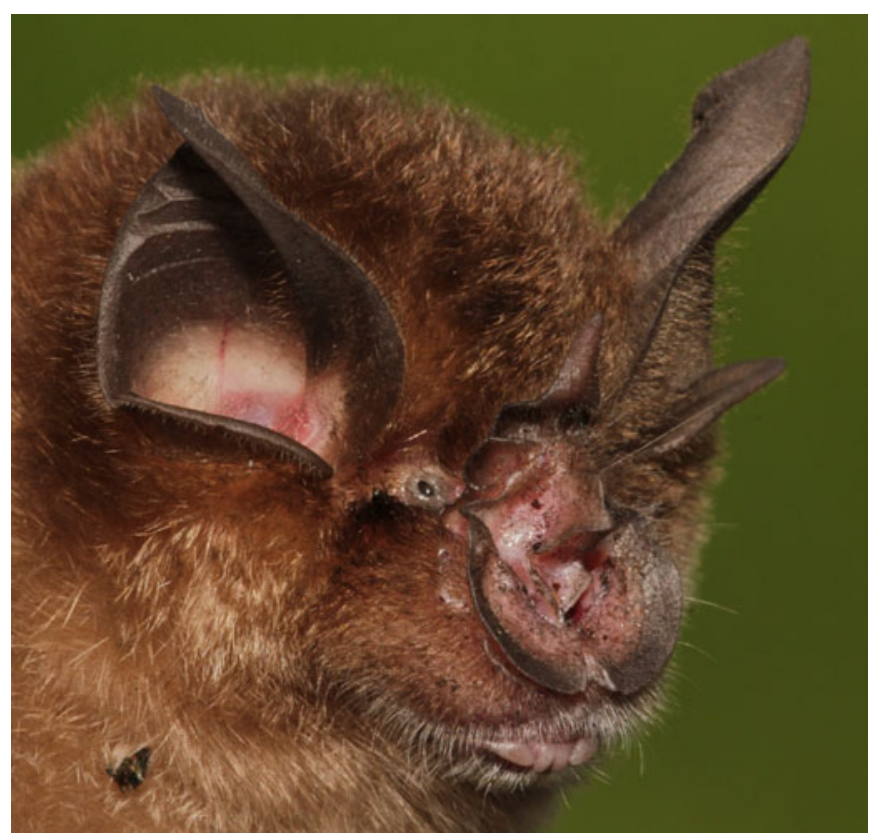

Rhinolophus stheno

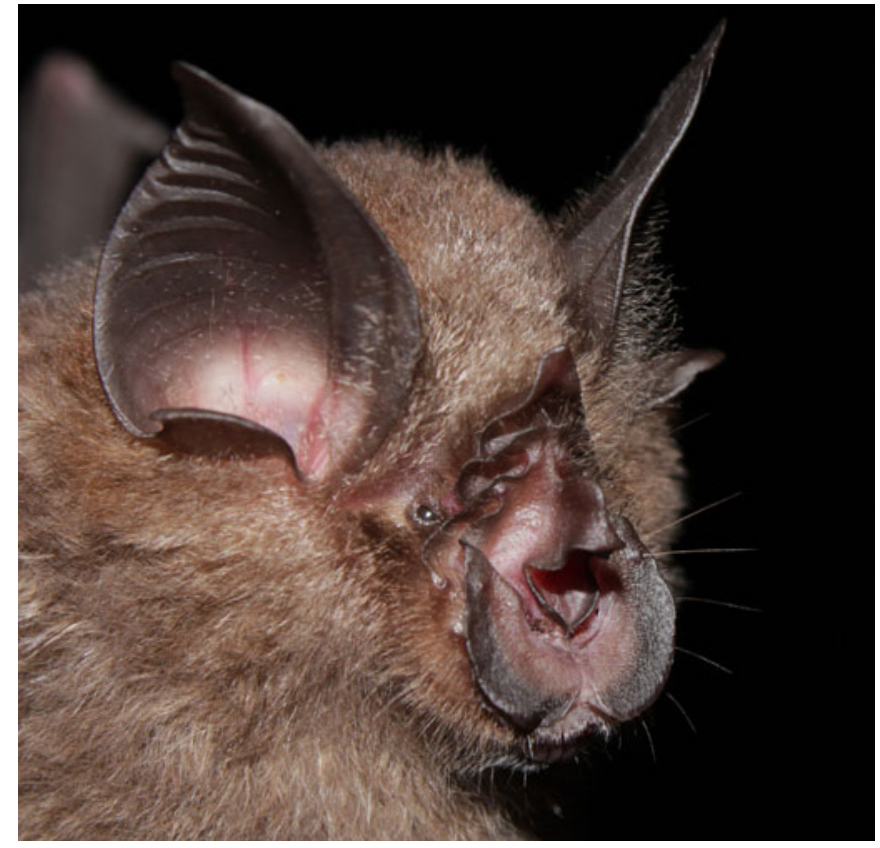

Rhinolophus robinsoni

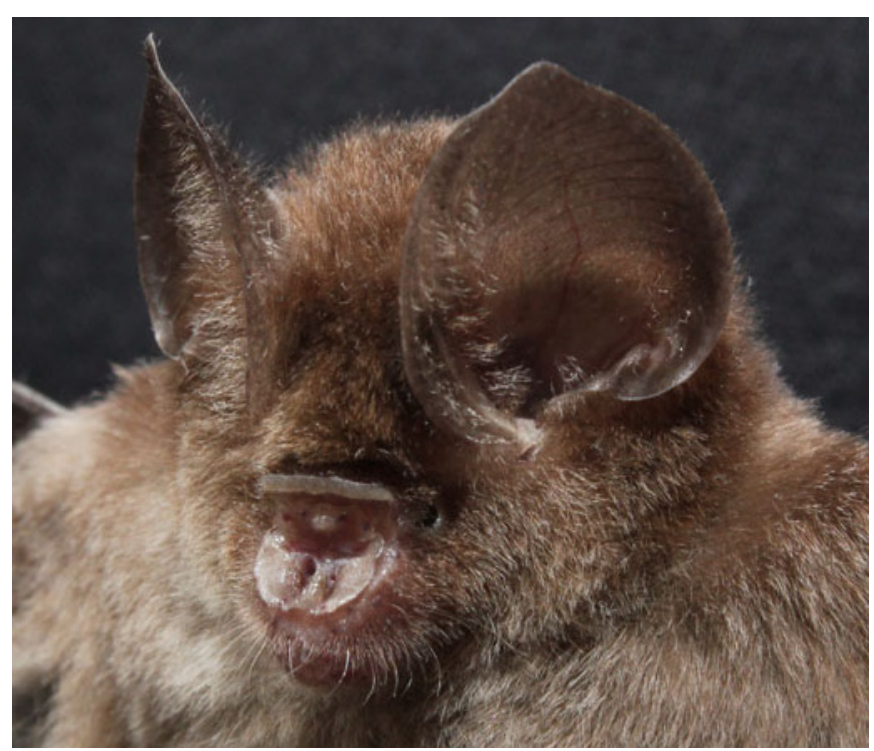

Hipposideros bicolor

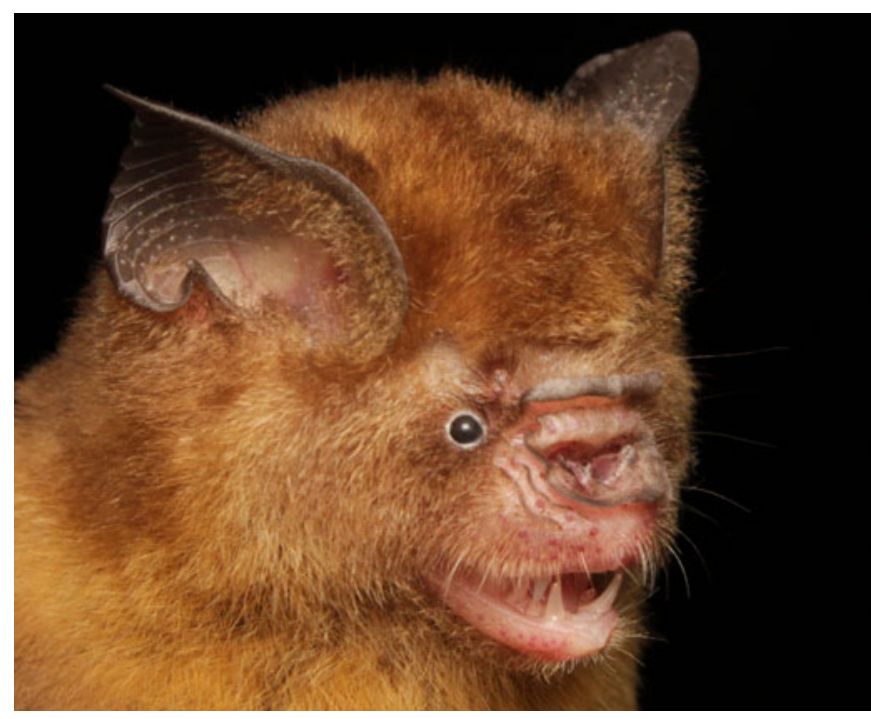

Hipposideros cervinus 


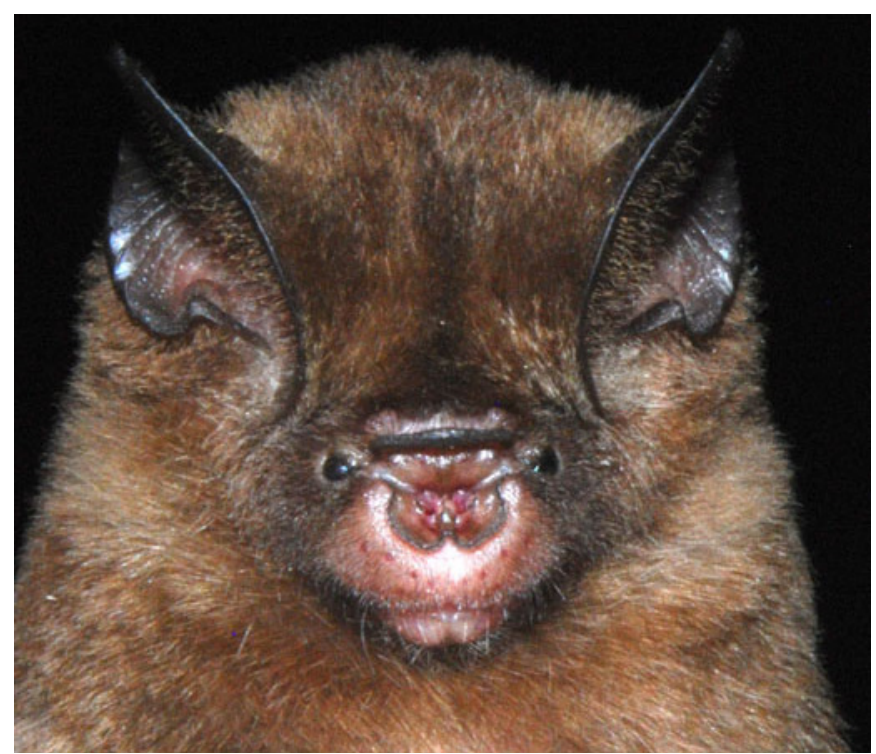

Hipposideros doriae

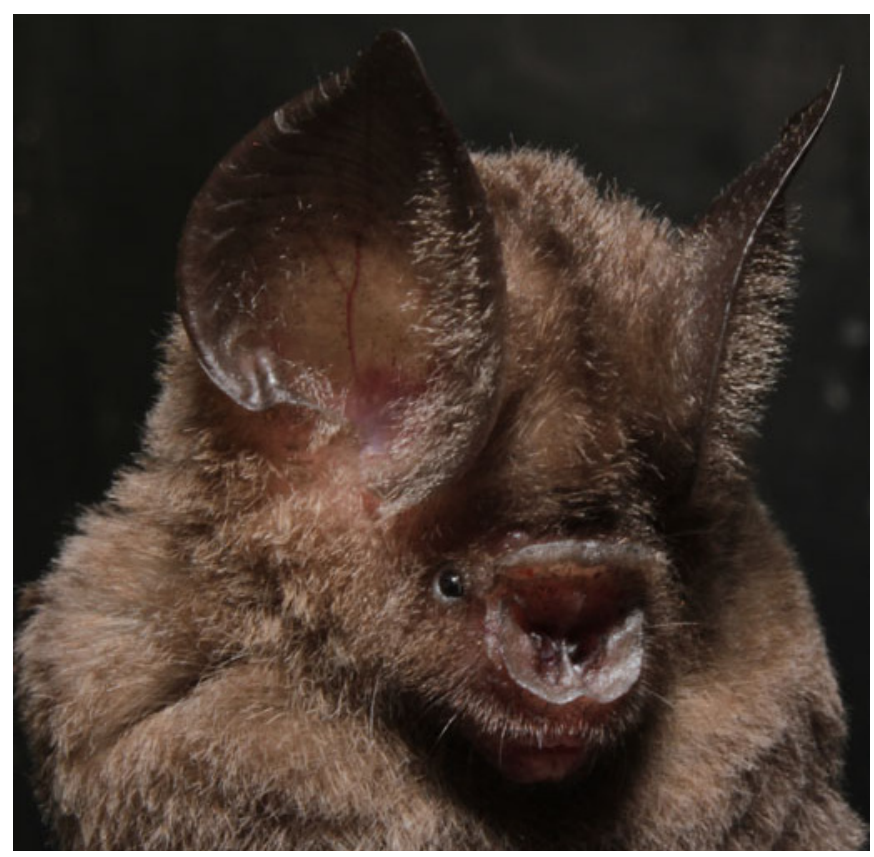

Hipposideros dyacorum

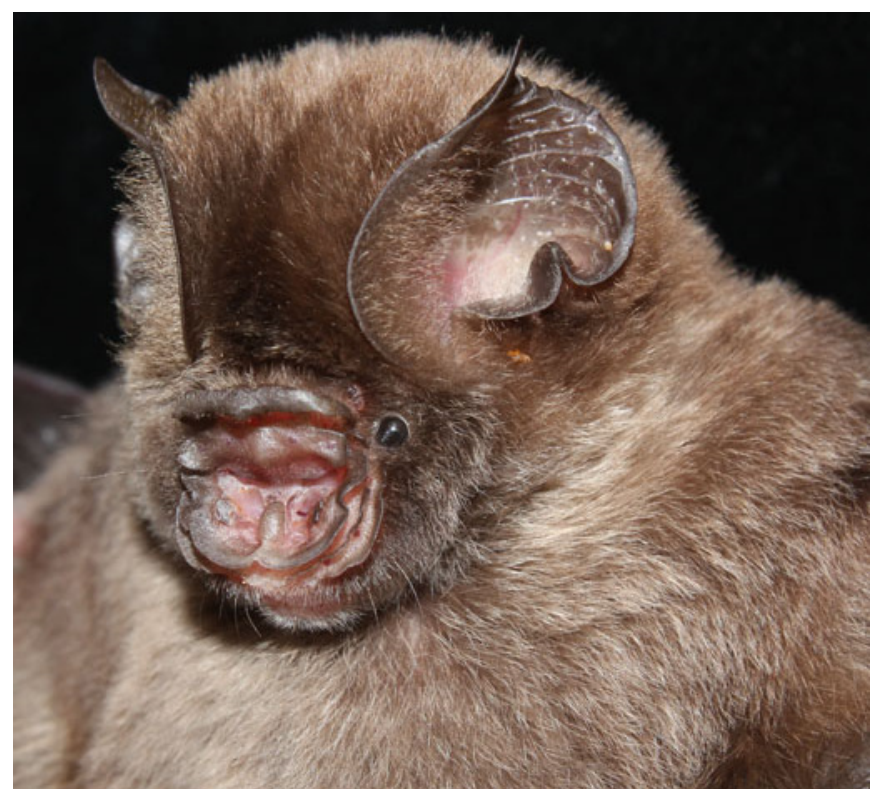

Hipposideros galeritus

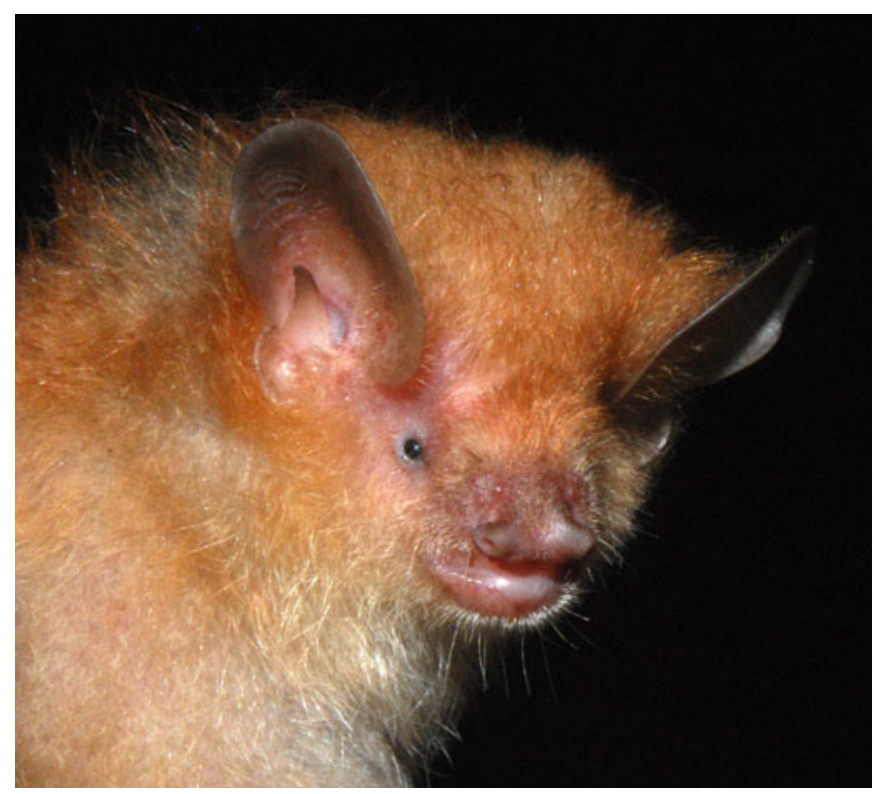

Murina peninsularis

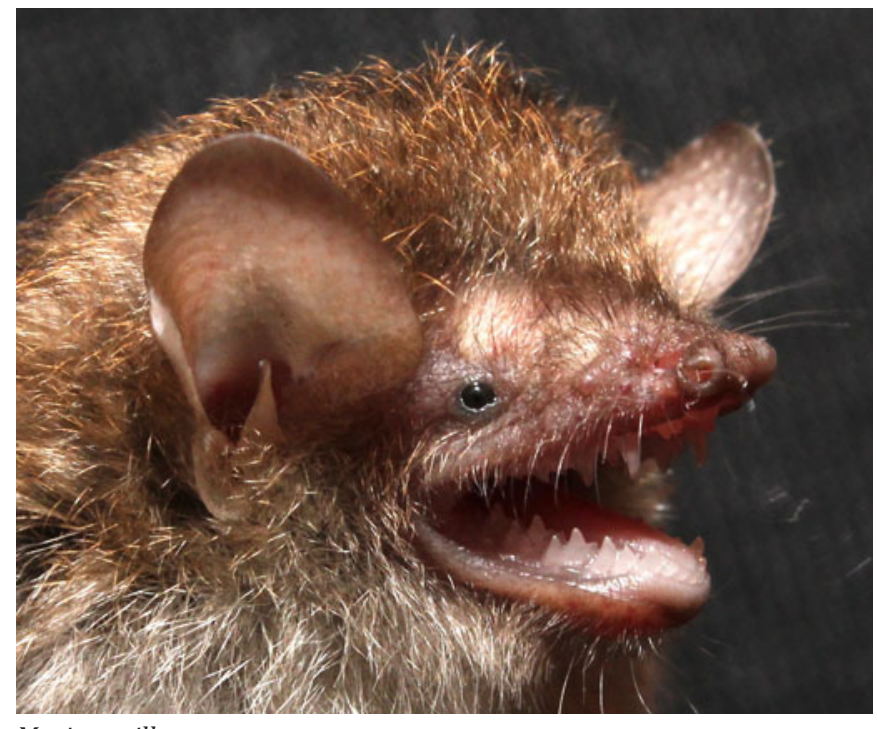

Murina suilla

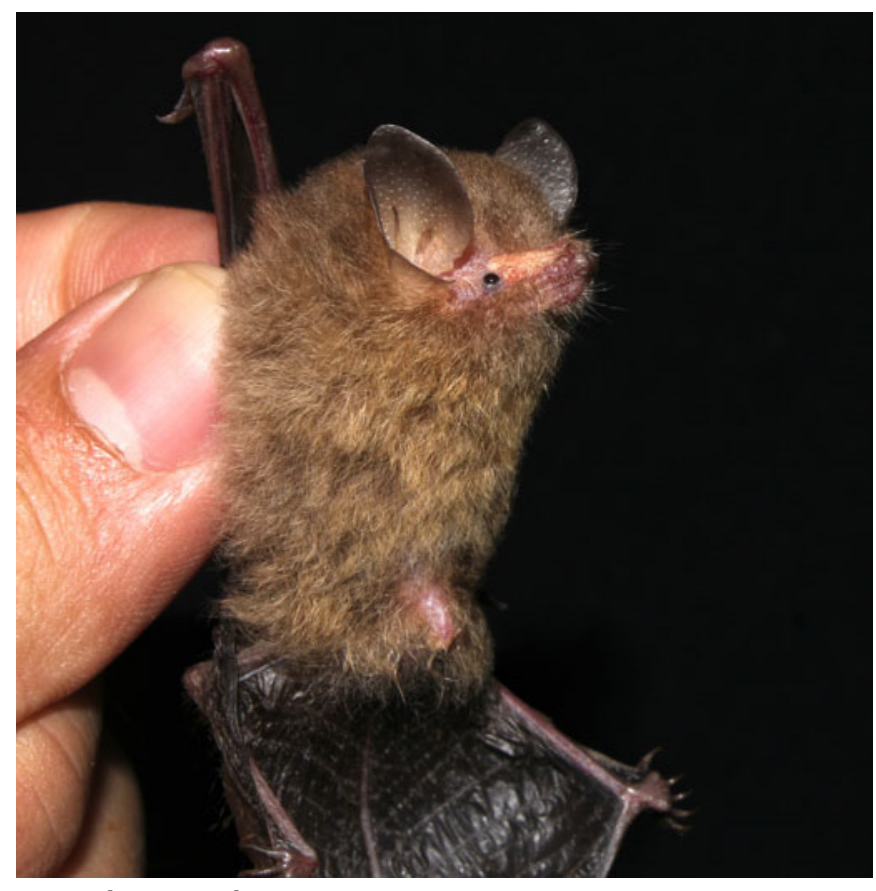

Kerivoula intermedia 


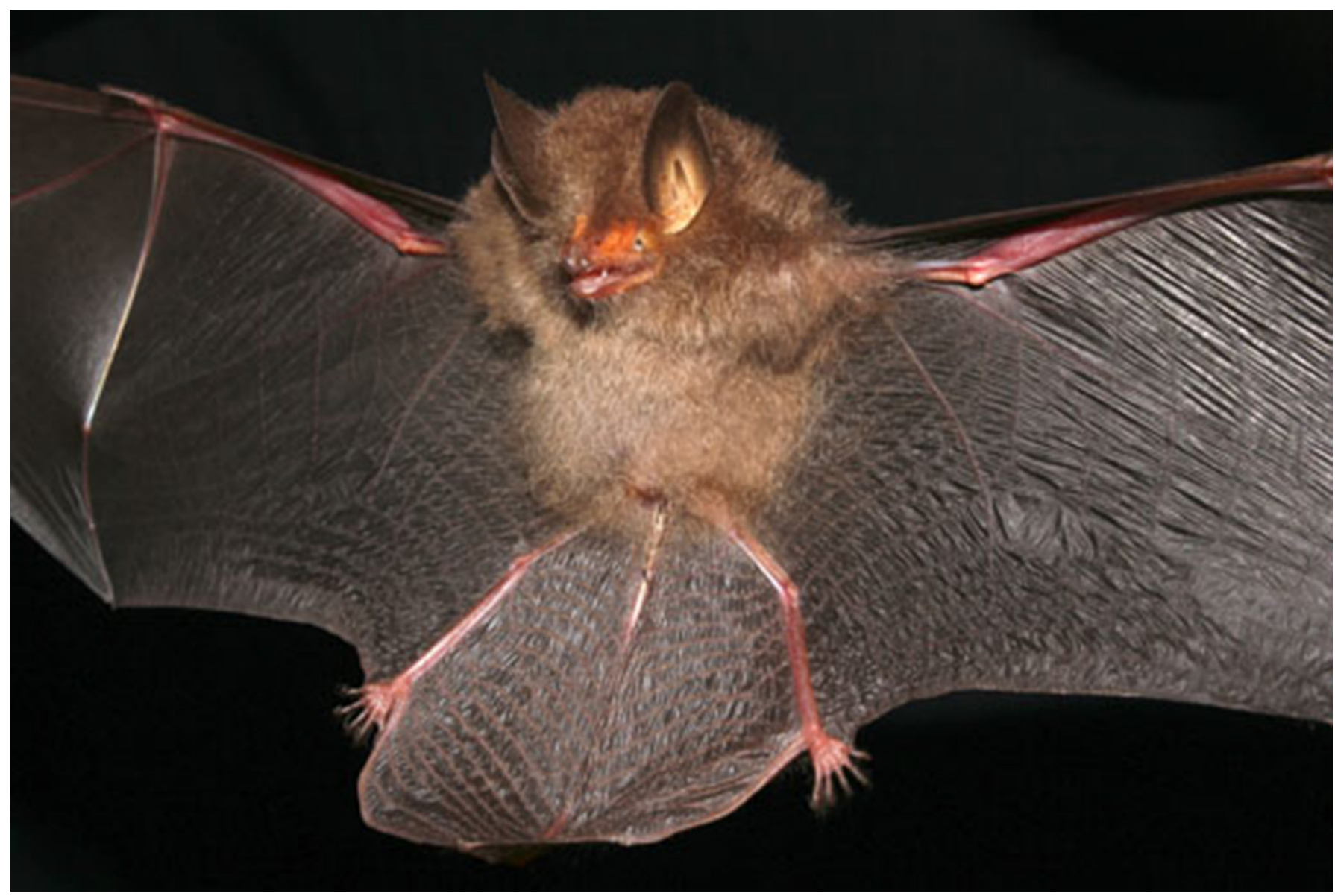

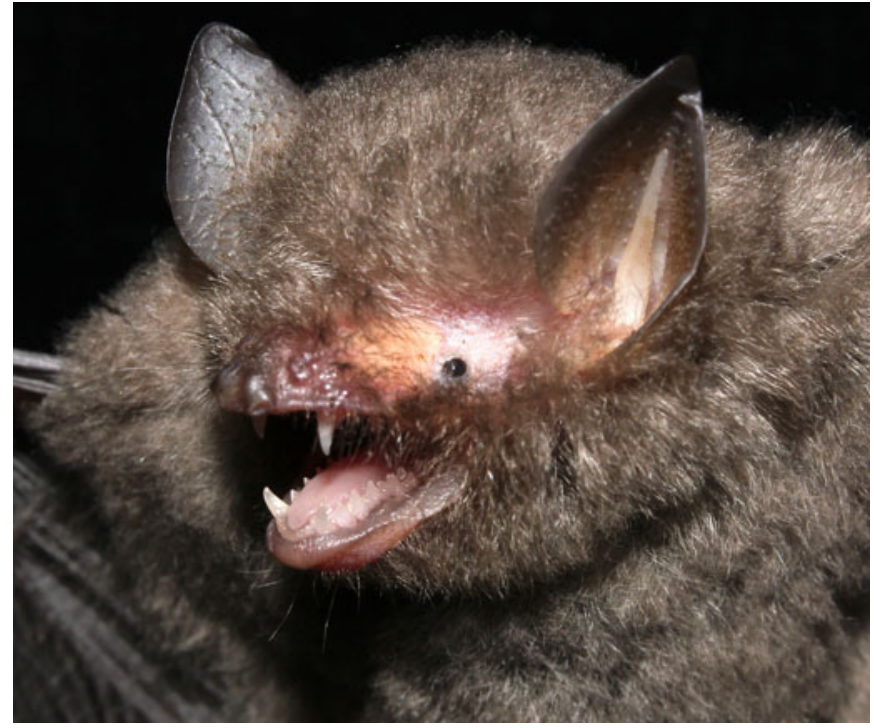

Kerivoula papillosa

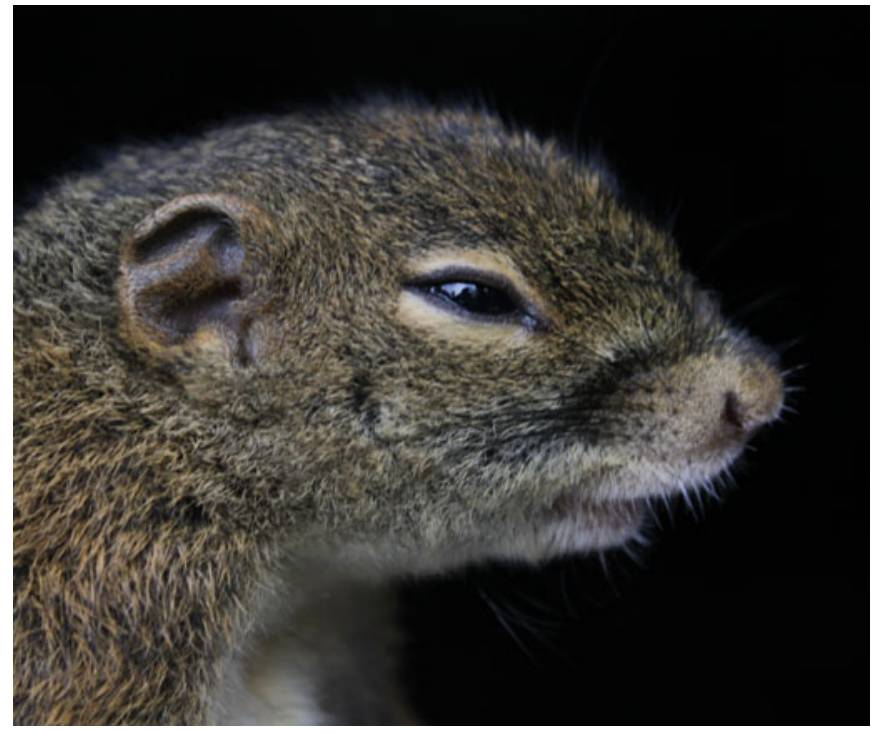

Sundasciurus tenuis 